\title{
Commentary
}

\section{Some observations about air quality in dense, low- income settlements}

\author{
Christiaan Pauw (i) \\ Nova Institute, 13 Beuke Place, The Willow Extension 14, South Africa \\ Christiaan.pauw@nova.org.za
}

https://doi.org/10.17159/caj/2020/30/1.8405

For decades, research on air pollution in low-income urban areas of South Africa has emphasised domestic solid fuel burning as an important source of pollution. In the Vaal Triangle and Mpumalanga Highveld, domestic coal use, especially for space heating in winter, was the subject of much research and a number of successful interventions.

Formalisation of housing, electrification, reduced availability of coal burning devices (due to the closing of the Falkirk plant in Newcastle and the fact that paint is not sold in metal tins anymore) in addition to above inflation increases in the price of coal, lead to a steady decrease in the proportion of households who use coal. A recent analysis of long-term trends in air quality in the Vaal Triangle Airshed Priority Area and the Highveld Priority Area (Feig et al. 2019) showed that there is indeed a steady, albeit in some cases slow, decrease in particulate concentrations in these areas.

There is certainly progress in the fight against air pollution in low-income urban areas. There are however counter forces. I will briefly discuss the following: population growth, urbanisation, electricity price increases and supply disruptions, collapse of infrastructure and failure of services.

Population growth. Comparison of the last three national censuses shows that although there is a large drop in the proportion of households who use solid fuels as their primary energy source for domestic cooking or heating, the drop in absolute numbers is not as dramatic. Between 1996 and 2011, the proportion of households who use wood as their primary energy source for cooking dropped from $22.9 \%$ to $13 \%$. When the absolute numbers are compared, the picture is less dramatic. In 1996, a total of 2,07 million households used wood for cooking, this increased to 2,3 million in 2001 and decreased to 1,8 million in 2011 (Statistics South Africa 2004, Statistics South Africa 2012). This means that the almost $10 \%$ proportional decrease in woodusing households only corresponds to an absolute decrease of only around 265000 fewer households. The future number of people exposed to air pollution from domestic sources will depend on the race between population growth, and economic and technological development.
Urbanisation. In 1996, 57.6\% of 42.24 million people in South Africa lived in areas classified as urban (Statistics South Africa 2003). This increased to $66 \%$ of 57,78 million people in 2018 . This means that over a period of just over two decades, the population of urban areas in South Africa has increased by almost 14 million people. To place this in perspective: over the same period the total growth in population was approximately 15.5 million people.

In spatial terms, one of the ways in which the phenomenon of urbanisation happens is as a cycle of settlement, densification, de-densification and re-densification. Settlement: This cycle starts with the informal settlement of an area of vacant land. This may take place organically at the fringes of settlements. It may also happen in an organised manner - evidenced by regular layout and sudden appearance of structures. In the beginning of such a new settlement, structures may be small and are spaced sparsely. Densification: After its initial establishment, settlements typically densify over time as more and larger structures are erected. Partial formalisation may also take place as services are provided and formal structures either allowed or provided. In cases where informal settlements are been upgraded in-situ, households may keep their informal structures or erect new ones next to the new formal houses (either for own use or as rental units). De-densification: De-densification of an already settled area corresponds to the settlement of a new area by backyard dwellers who want a place of their own. Redensification: Takes place when backyard shack are let out to new tenants after the original tenants have moved away due to a settlement event.

Electricity price increases and supply disruptions. Most of the readers of this journal will not need to be convinced that electricity prices have increased dramatically since 2008 and that supply interruptions are episodically common. Using solid fuels is not as comfortable as using electricity but it remains effective and economical in situations where bulk thermal energy is required. This is the reason why more households use solid fuels for space heating than for cooking. The more expensive and unreliable electricity becomes, the stronger the incentive towards solid fuel use. We also have recently started observing

${ }^{1}$ It is well known that households in South Africa often use a mix of energy carrier and that therefore total solid fuel use is drastically underestimated by the census (see Pauw et al. 2013). 
a growing use of liquid petroleum gas (LPG) - attributed by respondents to unreliable electricity supply.

Service delivery failure. Absence or failure of waste removal services is common in dense, low-income settlements in South Africa. Residents resort to alternative waste management practices that include using informal waste dumps. The physical and social geography of these dumping areas are interesting; they are typically situated relatively close to households (determined by how far one can comfortably walk with a wheelbarrow) on a piece of no-mans land. These sites can remain stable over years. In Sharpeville we tracked an informal dumping site that remained on the same side of the footpath for nine years. The stability of these sites and their predictable locations show that this practice should not be seen as simple littering. Given the circumstances, burning waste on private stands or at communal waste heaps is not a completely unreasonable course of action. Compared to research on domestic fuel use there is little research on the extent and possible solutions to urban waste burning.

The underlying cause of the type of air pollution specific to dense, low-income settlements in South Africa is poverty. People generally do not like to live in dust and smoke, and take measures to avoid it if they have the means to do so. A recent study has shown how air quality in two settlements (Kwazamokuhle and Hendrina) located very close to each other differ dramatically. The main underlying reason why air quality in Kwazamokuhle is so different from Hendrina is because average income in Hendrina is higher and has been higher for decades.

It is investment in infrastructure and long-term and equitable economic growth that will eventually reduce air pollution from unpaved roads, waste burning and domestic solid fuel use. Where this has taken place (e.g. provision of formal houses and electricity), the successes are already apparent.

\section{References}

Feig G., Garland, R.M., Naidoo S., Maluleke, A. and Van der Merwe, M. 2019. "Assessment of changes in concentrations of selected criteria pollutants in the Vaal and Highveld Priority Areas." Clean Air Journal 29 (2). https://doi.org/10.17159/caj/2019/29/2.7464.

Pauw, C. J., Fisher, T., Weston, M., Preston-Whyte, F., and Badenhorst, H. 2013. "The elephant in the room: What do we know about urban wood use in South Africa?" Presented at 16th IUPPA World Clean Air Congress, Cape Town, 3 October 2013.

Statistics South Africa. 2003. Census 2001: Investigation into Appropriate Definitions of Urban and Rural Areas for South Africa: Discussion Document. Pretoria: Statistics South Africa.

Statistics South Africa.. 2004. Census 2001: Primary Tables South Africa: 1996 and 2001 Compared. Report No. 03-02-04 (2001).
Pretoria: Statistics South Africa. http://www.statssa.gov.za/ publications/Report-03-02-04/Report-03-02-042001.pdf.

Statistics South Africa.. 2012. "Census 2011: Statistical Release." P0301.4. Pretoria: Statistics South Africa. 